\title{
Analisis Beban Pencemar Total Nitrogen dan Total Fosfat akibat Aktivitas Antropogenik di Danau Maninjau
}

\author{
Roselyn Indah Kurniati*, Puti Sri Komala, dan Zulkarnaini
}

Program Studi Magister Teknik Lingkungan, Fakultas Teknik Universitas Andalas; e-mail : indahroselyn@gmail.com (Roselyn Indah Kurniati), putisrikomala@eng.unand.ac.id (Puti Sri Komala), zulkarnaini@eng.unand.ac.id (Zulkarnain)

\begin{abstract}
ABSTRAK
Penelitian ini bertujuan untuk menganalisis beban pencemar dan daya tampung total nitrogen (TN) dan total fosfat (TP) akibat dari aktivitas antropogenik di Danau Maninjau. Perhitungan beban pencemar untuk aktivitas penduduk, pertanian, peternakan dan jumlah tamu hotel menggunakan Rapid Assesment. Penetapan beban pencemar KJA dan daya tampungyang mengacu kepada Peraturan Menteri Lingkungan Hidup No 28 Tahun 2009. Lokasi penelitian yang ditetapkan berdasarkan SNI 6989.57:2008 terdiri dari 10 lokasi yaitu tengah danau, PLTA, KJA, inlet dan outlet danau. Uji ANOVA dengan tingkat kepercayaan 95\% digunakan dalam melihat perbedaan data konsentrasi TN dan TP secara waktu pengambilan sampel dan lokasi sampling. Rasio TN:TP dievaluasi untuk mengetahui pembatas kesuburan perairan dan korelasinya terhadap klorofil.Konsentrasi TN berada pada rentang 0,42 - 0,95 mg/L, TP berkisar 0,18-0,66 mg/L dan klorofil-a 5,49-8,69 mg/m3. Hasil uji ANOVA, konsentrasi TN dan TP secara waktu pengambilan sampel tidak berbeda secara signifikan yaitu 0,64 dan 0,88 sedangkan secara lokasi sampling berbeda secara signifikan dengan nilai signifikansi 0,01 dan 4,03×10-6. TN dan TP memiliki hubungan yang kuat terhadap klorofil dan diperoleh rasio TN:TP<10 yang mengindikasikan nitrogen sebagai pembatas kesuburan. Beban pencemar TN dan TP terbesar berasal dari KJA yang menyumbang hampir 84,20 \% dan 91,83\% dari total beban pencemar. Ditinjau dari daya tampung mesotrofik beban pencemar TN belum melebihi sedangkan TP telah melebihi daya tampung sehingga perlu pengurangan hingga 71,34\% untuk mesotrofik dan 90,44\% untuk oligotrofik. Secara keseluruhan status trofik Danau Maninjau berada pada kondisi eutrofik dengan index 63,39.
\end{abstract}

Kata kunci: Antropogenik, Beban Pencemar, Danau Maninjau, Daya Tampung, Total Nitrogen dan Total Fosfat

\begin{abstract}
This study aims to analyze the pollutant load and the capacity of total nitrogen (TN) and total phosphate (TP) resulting from anthropogenic activities in Lake Maninjau. Calculation of the pollutant load for the activities of the population, agriculture, livestock and the number of hotel guests using Rapid Assessment. Determination of KJA pollutant load and carrying capacity refers to the Regulation of the Minister of Environment No. 28 of 2009. The research locations determined based on SNI 6989.57: 2008 consist of 10 locations, namely the middle of the lake, hydropower plant, marine cage, inlet and outlet. ANOVA test with a $95 \%$ confidence level was used to see the differences in TN and TP concentration data in terms of sampling time and sampling location. The TN: TP ratio was evaluated to determine the limitation of water fertility and its correlation to chlorophyll. TN concentrations were in the range $0.42-0.95 \mathrm{mg} / \mathrm{L}$, TP ranged from 0.18 to $0.66 \mathrm{mg} / \mathrm{L}$ and chlorophyll-a was $5.49 .-8.69 \mathrm{mg} /$ $\mathrm{m} 3$. ANOVA test results, TN and TP concentrations at sampling time did not differ significantly, namely 0.64 and 0.88 , while the sampling location was significantly different with a significance value of 0.01 and $4.03 \times 10-6$. TN and TP had a strong relationship to chlorophyll and the TN: TP ratio was obtained $<10$, which indicates nitrogen as a fertility limiter. The largest TN and TP pollutant load comes from KJA which accounts for almost $84.20 \%$ and $91.83 \%$ of the total pollutant load. Judging from the mesotrophic capacity of the TN pollutant load has not exceeded while the TP has exceeded the capacity so that it needs a reduction of up to $71.34 \%$ for mesotrophic and $90.44 \%$ for oligotrophic. Overall, the trophic status of Lake Maninjau is in a eutrophic condition with an index of 63.39 .
\end{abstract}

Keywords: Anthropogenic, Pollutant Load, Lake Maninjau, Capacity, Total Nitrogen and Total Phosphate

Citation: Kurniati, R.I., Komala, P.S., dan Zulkarnaini. (2021). Analisis Beban Pencemar Total Nitrogen dan Total Fosfat akibat Aktivitas Antropogenik di Danau Maninjau. Jurnal Ilmu Lingkungan, 19(2), 355-364, doi:10.14710/jil.19.2.355-364

\section{Pendahuluan}

Peningkatan aktvitas antropogenik yang terus menerus akan diikuti oleh meningkatnya produksi beban pencemar. Beban pencemar yang dibuang ke badan air secara terus menerus dapat mengakibatkan terjadinya pencemaran sehingga terjadi penurunan kualitas air (Gunes, 2008). Danau Maninjau salah satu badan perairan yang menerima beban pencemar dari aktivitas antropogenik. Beberapa aktivitas

*Penulis korespondensi: indahroselyn@gmail.com 
antropogenik yang mempengaruhi kualitas air Danau Maninjau adalah pemukiman, pertanian, peternakan, industri, dan keramba jaring apung (KJA). Aktivitas ini memberikan masukan bahan organik, nutrien maupun logam ke ekosistem sungai maupun danau melalui perubahan penggunaan lahan (Boqiang et al, 2013). Nitrogen dan fosfor merupakan salah satu parameter penyumbang beban pencemar yang menyebabkan terjadinya penurunan kualitas air (Lv et a., 2011).

KJA dan pemukiman adalah aktivitas utama yang mempengaruhi jumlah beban pencemar (Oakley, 2014). KJA menghasilkan beban pencemar yang mengandung total nitrogen (TN) dan total fosfat (TP) dari pakan dan metabolisme ikan (Beveridge, 2004). Tingginya TN dan TP yang dihasilkan tergantung kepada jumlah produksi ikan dan penggunaan pakan (Nguyen et al, 2014). Hal ini dapat dilihat dari perbedaan jumlah produksi ikan tahun 2011 dan 2013 yaitu 36.217 ton/tahun dan 23.947 ton/tahun yang menghasilkan beban pencemar TP sebesar 269,5 ton/tahun dan 220,2 ton/tahun (Lukman et al, 2015). Data dari Dinas Perikanan Kabupaten Agam, jumlah produksi ikan dan pakan di Danau Maninjau mengalami penurunan. Kondisi ini sedikit berbeda jika dilihat dari trend jumlah KJA di Danau Maninjau yang mengalami peningkatan hingga tahun 2018 kemudian menurun menjadi 12.312 unit pada tahun 2019 . Namun, penurunan jumlah KJA masih melebihi daya tampung yang diperbolehkan oleh Pemerintah Kabupaten Agam yaitu 6.000 petak (Peraturan Daerah Kabupaten Agam, 2014). Jumlah penduduk Kecamatan Tanjung Raya dari tahun 2010 sampai 2019 telah mengalami peningkatan dengan laju pertumbuhan hingga $0,74 \%$. Peningkatan jumlah penduduk akan berdampak terhadap beban pencemar yang dihasilkan. Aktivitas penduduk seperti mencuci, feses dan urin akan menghasilkan limbah cair yang memiliki kandungan TN dan TP (Vinnerås, 2001). Hal ini terlihat dari penurunan kualitas air Sungai Caraha akibat dari peningkatan jumlah penduduk yang mengakibatkan tingginya kandungan TN dan TP (Quinatto et al, 2018). Dengan adanya perubahan jumlah penduduk dan KJA setiap tahunnya akan mempengaruhi jumlah beban pencemar TN dan TP yang dihasilkan serta daya tampungnya. Oleh karena itu perlu adanya perhitungan beban pencemar kembali dan membatasinya dengan menghitung daya tampung untuk menjaga kualitas air sesuai standar yang ditetapkan.

Penelitian terkait beban pencemar dan daya tampung telah dilakukan oleh Machub dengan menghitung beban pencemar TP dari aktivitas antropogenik seperti KJA, pemukiman, pertanian, peternakan, erosi hutan serta daya tampung untuk kondisi mesotrofik di Danau Maninjau (Machbub, 2010). Perhitungan dan parameter yang sama juga dilakukan di Danau Toba, namun beban pencemar yang dihitung adalah KJA, pemukiman, peternakan dan sawah (Oakley, 2014). Penelitian-penelitian diatas menunjukan perhitungan beban pencemar dan pembatasan hanya dilakukan untuk parameter TP saja, sedangkan TN juga menjadi salah satu parameter terbesar penghasil beban pencemar. Oleh karena itu perlu adanya perhitungan beban pencemar dan daya tampung TN untuk melihat pengaruh TN di Danau Maninjau. Penelitian ini bertujuan untuk mengetahui kondisi beban pencemar TN dan TP yang dihasilkan pada saat ini. Aktivitas antropogenik yang dihitung dalam penelitian ini adalah KJA, pemukiman, pertanian, peternakan dan hotel kemudian dilakukan pembatasan beban pencemar dengan menghtung daya tampung. Perhitungan daya tampung mengacu kepada Peraturan Menteri Lingkungan Hidup No 28 Tahun 2009 dan dalam penelitian ini juga dilihat status trofik danau.

\section{Bahan dan Metode}

\subsection{Waktu dan Lokasi Penelitian}

Penelitian ini dilaksanakan pada bulan Maret 2020 hingga Juli 2020 di Danau Maninjau, Sumatera Barat. Penentuan lokasi pengambilan sampel air untuk parameter TN dan TP di Danau Maninjau mengacu pada SNI 6989.57:200. Lokasi pengambilan sampel air terdiri dari 10 lokasi yaitu tengah danau, PLTA, KJA, inlet dan outlet danau (Gambar 1). Lokasi pengambilan sampel klorofil-a dan pengukuran kecerahan untuk penentuan status trofik dilakukan di tengah danau, PLTA dan KJA sedangkan lokasi pengambilan sampel ikan dan pakan untuk perhitungan beban pencemar KJA dilakukan di KJA Koto Malintang.

\subsection{Pengambilan Sampel}

Pengambilan sampel air untuk parameter TN dan TP di Danau dilakukan berdasarkan komposit kedalaman sementara inlet dan outlet danau diambil pada 1 titik yaitu tengah sungai karena debit sungai kecil dari $5 \mathrm{~m}^{3} / \mathrm{s}$. Pengambilan sampel menggunakan vertical water sampler menggunakan transportasi boat sedangkan untuk inlet dan outlet danau langsung diambil menggunakan botol sampel ukuran 1 Liter. Sampel kemudian diawetkan menggunakan $\mathrm{H}_{2} \mathrm{SO}_{4}$ hingga $\mathrm{pH}$ mencapai 2 ( \pm 10 tetes) dan disimpan di dalam coolbox sebelum dianalisis di Laboratorium.

Pengambilan sampel klorofil-a menggunakan plankton net No 31. Pengambilan sampel di tengah danau dan KJA dilakukan dari kedalaman 10 m hingga permukaan secara langsung sedangkan PLTA dari kedalaman 3m hingga permukaan. Sampel disimpan pada botol sampel berukuran $30 \mathrm{~mL}$ dan dibungkus dengan aluminium foil kemudian dimasukkan dalam coolbox. Kecerahan diukur menggunakan sechi disk.

Jenis ikan yang dianalisis adalah Ikan Nila yaitu jenis ikan dengan budidaya terbanyak di KJA Danau Maninjau. Sampel ikan diambil sebanyak 3 ekor dalam sekali pengambilan sampel dengan ukuran $\pm 20 \mathrm{~cm}$ (250 gr). Sampel dibungkus dengan aluminium foil dan diletakkan pada coolbox. Pakan yang dianalisis adalah pakan yang sering digunakan yaitu jenis pakan tenggelam dengan merk Bintang. Sampel disimpan pada bungkus plastik bening sebelum dianalisis. 


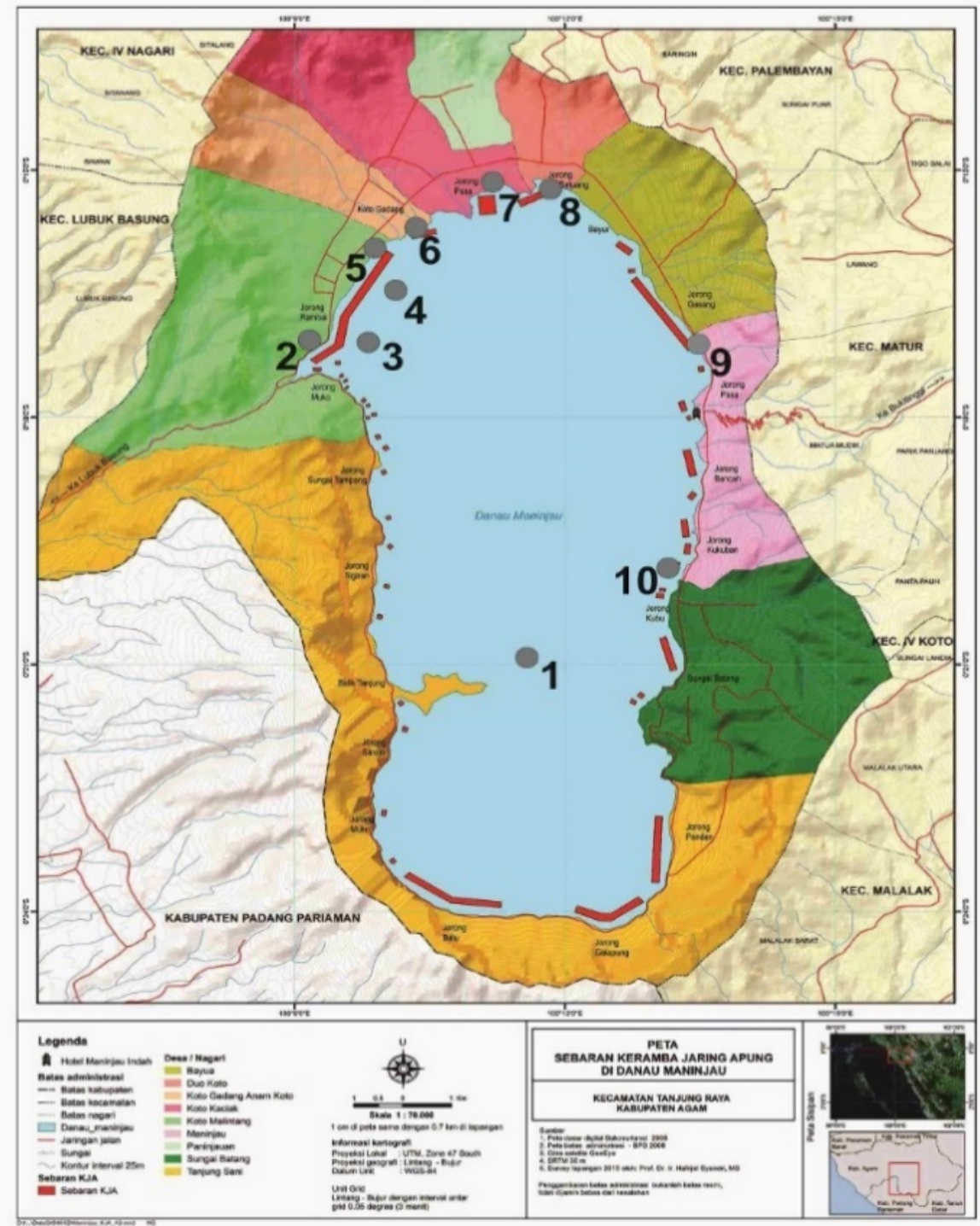

Gambar 1. Lokasi Penelitian

Keterangan : (1) Tengah Danau (2) Batang Antokan (3) PLTA (4) KJA (5) Sungai Kurambit (6) Sungai Kularian (7) Banda Baluran (8) Sungai Maransi (9) Sungai Bandar Ligin (10) Sungai Tanjung Sani

Preparasi sampel ikan dan pakan dilakukan dengan menggerus sampel kemudian melarutkan sampel dengan $100 \mathrm{~mL}$ aquadest dalam 1 gr. Pengadukan sampel dilakukan menggunakan shaker dengan kecepatan 100 rpm dalam 30 menit. Sampel yang akan dianalisis adalah sampel yang telah dilakukan penyaringan.

\subsection{Penyebaran Kuisioner}

Kuisioner bertujuan untuk mengetahui sistem pengolahan limbah cair (pemukiman dan hotel), penggunaan pupuk dan peptisida (pertanian), penggunaan pakan, jenis pakan dan merk pakan (KJA), dan makanan hewan (peternakan). Penentuan jumlah responden memerlukan data jumlah penduduk, petani, hotel, peternak dan pemilik KJA yang diperoleh daru BPS Kecamatan Tanjung Raya dan dihitung menggunakan teknik solvin. Perhitungan jumlah responden kuisioner untuk masing-masing sumber menggunakan rumus:

$$
n=\frac{N}{1+N e^{2}}
$$

Keterangan :

$$
\begin{array}{ll}
\mathrm{n} & =\text { jumlah sampel } \\
\mathrm{N} & =\text { jumlah populasi } \\
\mathrm{e} & =\text { perkiraan tingkat kesalahan }(10 \%)
\end{array}
$$


Dari persamaan diatas didapatkan jumlah responden kuisioner untuk masing-masing sumber pencemar yaitu 100 untuk pemukiman, 55 untuk pertanian, 94 untuk KJA, 12 untuk hotel dan 64 untuk peternakan.

\subsection{Metode Analisis Data}

Analisis sampel air untuk parameter TN mengacu kepada Standar Methods For The Examination Of Water And Wastewater 1995, analisis TP mengacu kepada SNI 06.6989.31.2005, dan analisis sampel klorofil-a menggunakan metoda Acetone Method Using Spectrophometer.

Analisis statistik yang digunakan untuk melihat perbedaan data konsentrasi TN dan TP secara spasial dan temporal menggunakan ANOVA one way dengan tingkat kepercyaan $95 \%$ atau nilai signifikansi 0,05. Jika nilai signifikansi (P) $>0,05$ maka tidak ada perbedaan yang signifikan dan kondisi yang berbeda signifikan jika $(P)<0,05$. Hubungan TN dan TP terhadap klorofil-a menggunakan regresi sederhana dengan melihat nilai korelasi $(\mathrm{r})$.

Status trofik danau digunakan untuk mengetahui tingkat kesuburan perairan dengan melihat 4 parameter yaitu TN, TP, klorofil-a dan kecerahan. Penentuan status trofik danau menggunakan Trophic State Index (TSI) (Carlson, 1977).

$$
\begin{aligned}
& T S I(T N)=14.42 \ln (T N)+4.15 \\
& T S I(T P)=54.45 \ln (T P)+4.15 \\
& T S I(\text { Klorofil })=9,81 \ln (\text { klorofil })+30,6 \\
& T S I(\text { kecerahan })=60-14,41 \ln (\text { kecerahan })(5) \\
& \sum T S I=T S I \frac{(\text { TN }+ \text { TP }+ \text { klorofil+kecerahan })}{4}
\end{aligned}
$$

Akumulasi dari nilai TSI yang diperoleh dibandingkan dengan klasifikasi status trofik yaitu index $<40$ menunjukan kondisi oligotrofik, $>40-50$ mesotrofik, $>50-70$ eutrofik dan $>70$ hipertrofik.

Perhitungan beban pencemar TN dan TP yang berasal dari pemukiman, pertanian, hotel dan peternakan mengacu pada Rapid Assesmant. Data yang dibutuhkan dalam perhitungan beban pencemar meliputi jumlah penduduk, luas lahan sawah, jumlah hewan ternak dan jumlah tamu hotel diperoleh dari Badan Pusat Statistika (BPS) Kecamatan Tanjung Raya. Faktor emisi dari tiap-tiap unit pencemar dapat dilihat pada Tabel 1.

$B P=a x f$

Keterangan :

$\mathrm{BP}=$ beban pencemar $(\mathrm{kg} /$ tahun $)$

a = jumlah penduduk, hewan, tamu hotel dan luas sawah

$\mathrm{f} \quad=$ faktor emisi (g/hari) Perhitungan beban pencemar TN dan TP yang berasal dari KJA dihitung menggunakan rumus:

$$
B P=\left(F C R \times T N / T P_{\text {pakan }}\right)-T N / T P_{\text {ikan }}
$$

Keterangan :

$$
\begin{array}{ll}
\mathrm{BP} & =\text { beban pencemar } \mathrm{KJA}(\mathrm{kg} / \mathrm{tahun}) \\
\mathrm{FCR} & =\text { food conversion rate }(1.47) \\
\mathrm{TN} / \mathrm{TP}_{\text {pakan }} & =\text { kandungan TN dan TP pada pakan } \\
& \text { (kg/ton) } \\
\mathrm{TN} / \mathrm{TP}_{\text {ikan }} & =\text { kandungan TN dan TP pada ikan } \\
& \text { (kg/ton) }
\end{array}
$$

Akumulasi beban pencemar TN dan TP dibandingkan dengan daya tampung.

Perhitungan daya tampung TN dan TP mengacu pada mesotrofik dan oligotrofik berdasarkan Peraturan Menteri Lingkungan Hidup No 28 Tahun 2009. Untuk perhitungan daya tampung memerlukan data morfometri dan hidrologi danau (Tabel 2).

Tabel 1. Faktor Emisi TN Dan TP

\begin{tabular}{lccc}
\hline \multicolumn{1}{c}{ Aktivitas } & Satuan & TN & TP \\
\hline Pemukiman & & \\
Septik tank & g/hari & 5.4 & 0.9 \\
Tanpa septik tank & g/hari & 22.7 & 3.8 \\
$\begin{array}{l}\text { Pertanian } \\
\text { Sawah }\end{array}$ & & \\
Peternakan & Kg/tahun & 20 & 10 \\
Sapi & & \\
Kerbau & g/hari & 0.933 & 0.153 \\
Kambing & g/hari & 2.599 & 0.39 \\
Ayam & g/hari & 1.624 & 0.116 \\
Itik & g/hari & 0.02 & 0.03 \\
Hotel & g/hari & 0.001 & 0.005 \\
\hline raturan Menteri Lingkungan Hidup No 1 tahun 2010, BLK-PSDA Tahun 2013, BLK-PSDA Tahun 2004
\end{tabular}


Tabel 2. Morfometri dan Hidrologi Danau Maninjau

\begin{tabular}{lc}
\hline \multicolumn{1}{c}{ Morfometri dan Hidrologi } & Nilai \\
\hline$\hat{z}$, kedalaman rata-rata $(\mathrm{m})$ & 104.84 \\
$\rho$, laju penggantia n air (/tahun) & 0.043 \\
a, luas area $\left(\mathrm{m}^{2}\right)$ & 97630000 \\
\hline
\end{tabular}
rumus:

Daya tampung TN dan TP dihitung menggunakan $\quad x$

$L=\frac{B P_{s t d} x \hat{z} x \rho}{1-R}$

$L a=L x a$

Penentuan nilai $\mathrm{R}$ untuk parameter TN dan TP berbeda, untuk parameter TN dilakukan dengan rumus:

$$
R=\frac{1}{1+0,747 \rho^{0,507}}
$$

Nilai R untuk parameter TP dihitung dengan rumus:

$$
\begin{aligned}
& R=x+((1-x) s) \\
& s=\frac{1}{1+0,747 \rho^{0,507}}
\end{aligned}
$$

\section{Keterangan :}

$\mathrm{L} \quad=$ daya tampung TN/TP persatuan luas danau (gr/m².tahun)

$\mathrm{L}_{\mathrm{a}}=$ daya tampung pada perairan danau (gr/tahun)

$\mathrm{BP}_{\text {std }}=$ batas status trofik TN/TP oligotrofik dan mesotrofik $\left(\mathrm{mg} / \mathrm{m}^{3}\right)$

$\rho \quad$ = laju penggantian air (/tahun)

$\hat{\mathrm{Z}} \quad=$ kedalaman rata-rata danau $(\mathrm{m})$

= luas danau $\left(\mathrm{m}^{2}\right)$

= pengendapan $\mathrm{TN} / \mathrm{TP}$

$=\mathrm{TN} / \mathrm{TP}$ yang tinggal bersama sedimen
$=$ proporsi $\mathrm{TP}$ yang secara permanen masuk ke danau, $45-55 \%$

Hasil perhitungan daya tampung akan dibandingkan dengan total beban pencemar. Jika beban pencemar telah melebihi daya tampung, maka perlu adanya perhitungan dalam penurunan beban pencemar.

\section{Hasil dan Pembahasan}

\subsection{Konsentrasi Total Nitrogen dan Total Fosfat}

Gambar 2 menunjukan konsentrasi TN dan TP di seluruh lokasi pengamatan dan diperoleh konsentrasi TN lebih tinggi daripada TP di semua lokasi penelitian. Rata-rata konsentrasi TN dan TP berkisar antara 0.95$0.42 \mathrm{mg} / \mathrm{L}$ dan 0.66-0.18 mg/L, cenderung lebih tinggi pada lokasi KJA dan Sungai Bandar Ligin. Konsentrasi TN dan TP di KJA yaitu $0.95 \pm 0.131$ dan $0.66 \pm 0.054$ sedangkan di Sungai Bandar Ligin yaitu 0.69 \pm 0.060 dan $0.55 \pm 0.024$.

Tingginya konsentrasi TN dan TP yang berasal dari KJA menunjukan adanya akumulasi TN dan TP di perairan yang berasal dari limbah KJA sebagai salah satu sumber pasokan unsur hara yang masuk ke danau. Aktivitas budidaya perikanan menyumbang 65.1\% (TN) dan 62.6\% (TP) dalam bentuk terlarut sedangkan pakan menyumbang $71.4 \%$ fosfor dan $68-86 \%$ nitrogen ke lingkungan perairan dan sisanya dimakan oleh ikan (Mazón et al., 2007; Morris dan Price, 2015). Data diatas menunjukan bahwa nitrogen dan fosfor memberikan kontribusi yang besar terhadap perairan.

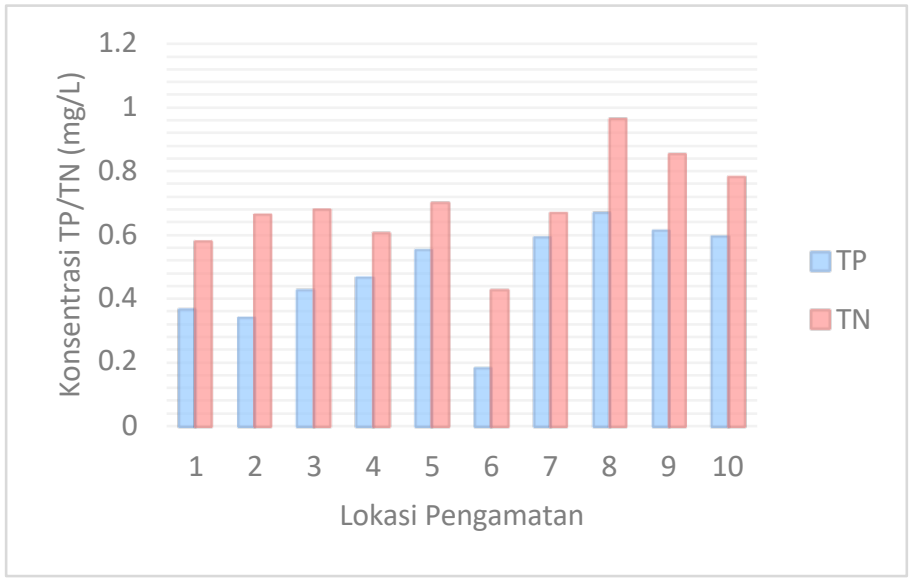

Gambar 2. Konsentrasi Total Fosfat dan Total Nitrogen di Lokasi Pengamatan 
Sumber TN dan TP lainnya yang masuk melalui inlet danau diperkirakan berasal dari kegiatan rumah tangga dan pertanian. Berdasarkan data Kecamatan Tanjung Raya dalam angka, Sungai Bandar Ligin berada pada Nagari Sungai Batang dan salah satu nagari yang memiliki lahan pertanian yang luas dan padat penduduk. Hasil dari penyebaran kuisioner pada petani diketahui bahwa pupuk yang sering digunakan adalah SP 36 dan urea. Jenis pupuk SP 36 mengandung $36 \%$ fosfor dan urea mengandung 46\% nitrogen (Suwarno, 2013). Sumber TN dan TP dari aktvitas rumah tangga seperti limbah yang berasal dari feses, urin dan detergen. Feses dalam bentuk kadar fosfor menyumbang $20-50 \%$ dan $10-20 \%$ dalam bentuk nitrogen (Vinnerås, 2001).

Konsentrasi terendah TN dan TP di Danau Maninjau berada pada tengah danau sedangkan pada aliran inlet berasal dari Sungai Tanjung Sani. Rendahnya konsentrasi TN dan TP di tengah danau disebabkan oleh jauhnya lokasi dari sumber aktivitas antropogenik. Secara visual Sungai Tanjung Sani memiliki warna yang cukup jernih dari sungai lainnya dan kecepatan aliran yang tinggi. Sungai Tanjung Sani berada pada lokasi yang minim penduduk dan sedikit aktivitas pertanian.

Secara spasial hasil uji ANOVA memperlihatkan nilai signifikansi konsentrasi TP dan TN terhadap waktu pengambilan sampel diperoleh 0,64 dan 0,88 $(\mathrm{P}>0.05)$ yang memperlihatkan tidak terjadinya perbedaan konsentrasi yang signifikan. Kondisi yang berbeda terjadi pada signifikansi terhadap lokasi sampling dengan $\mathrm{P}<0,05$ yaitu 0,01 dan $4,03 \times 10^{-6}$ yang menunjukan adanya perbedaan yang signifikan konsentrasi TN dan TP terhadap lokasi sampling. Penyebab terjadinya perbedaan yang signifikan diduga oleh jumlah beban yang masuk ke lokasi sampling berbeda akibat dari keragaman aktivitas penduduk sehingga mempengaruhi konsentrasi TN dan TP.

Hasil pengamatan dari semua lokasi diperoleh rasio TN:TP yaitu 1,43-2,33 yang menunjukan bahwa konsentrasi nitrogen sangat dominan pada perairan. Rasio TN:TP>17 menunjukan fosfor sebagai pembatas kesuburan namun jika TN:TP $<10$ maka nitrogen sebagai pembatas kesuburan. Berdasarkan kategori tersebut, rasio yang diperoleh $<10$ yang menandakan nitrogen sebagai pembatas kesuburan. Rasio $<10$ juga dilaporkan terjadi pada tahun 2000, 2011 dan $2018 \mathrm{di}$ Danau Maninjau yang mengakibatkan terjadinya blooming Microcystis aeruginasa (Sulastri et al., 2019). Blooming ini dicirikan dengan warna hijau pekat pada perairan dan kandungan klorofil hingga $100 \mathrm{mg} / \mathrm{m}^{3}$. Blooming Cyanobacteria juga terjadi pada perairan dengan konsentrasi nitrogen yang dominan atau rasio TN:TP yang rendah (Rathore et al., 2016). Selain blooming Microcystis aeruginasa dan Cyanobacteria, rasio TN:TP yang rendah juga mengakibatkan blooming Chrysophyta (Putri et al., 2008).

Rasio TN:TP > 17 terjadi pada tahun 2009, 2015 dan 2016 di Danau Maninjau (Sulastri et al., 2019). Kondisi ini ditandai dengan konsentrasi TP yang cukup tinggi dari tahun sebelumnya sehingga mengakibatkan blooming Cyanophyta. Selain Cyanophyta kelimpahan jenis lainnya yang terjadi akibat rasio > 17 adalah Cyanotoxins (Dolman et al, 2012). Blooming ini dapat mengeluarkan zat beracun sehingga membahayakan populasi yang ada pada perairan seperti kematian massal ikan (Chirico et al, 2020) Hal ini terbukti dengan adanya kematian massal ikan pada tahun 2009 di Danau Maninjau (Lukman et al, 2015)

\subsection{Klorofil-a}

Konsentrasi klorofil-a pada lokasi tengah danau, PLTA dan KJA berkisar antara 5,49-8,69 mg/m³. Konsentrasi tertinggi di KJA dan terendah pada tengah danau. Konsentrasi klorofil-a termasuk dalam kategori eutrofik yang mengacu kepada Peraturan Kementrian Lingkungan Hidup No 28 Tahun 2009. Kondisi ini merata pada seluruh lokasi pengambilan sampel. Klorofil yang diperoleh pada penelitian ini mengalami penurunan jika dibandingkan pada tahun sebelumnya akibat dari penurunan jumlah KJA di Danau Maninjau. Jumlah dan luas KJA dari tahun 2017-2019 mengalami penurunan hingga 0,23\% sehingga mempengaruhi konsentrasi klorofil di Danau Maninjau. Sulastri memperoleh konsentrasi klorofil-a berkisar 10,83 $\mathrm{mg} / \mathrm{m}^{3}-97,48 \mathrm{mg} / \mathrm{m}^{3}$ yang mengindikasikan kondisi eutrofik hingga hipertrofik (Sulastri et al, 2019). Secara visual kondisi perairan Danau Maninjau cukup jernih ditandai dengan kenaikan kecerahan. Penelitian sulastri memperoleh kecerahan hanya 1,8 m sedangkan pada penelitian ini meningkat menjadi 2,49 m.

Hubungan klorofil-a terhadap TN dan TP di Danau Maninjau mempunyai nilai korelasi (r) sebesar 0,98 dan 0,97 . Nilai korelasi (r) yang diperoleh menunjukan korelasi yang sangat kuat antara parameter TN dan TP terhadap konsentrasi klorofil-a. TN dan TP terhadap klorofil-a memiliki hubungan yang berbanding lurus. Konsentrasi TN memiliki hubungan yang lebih kuat terhadap konsentrasi klorofil-a dari TP, sama halnya dengan penelitian yang dilakukan oleh Filstrup (Filstrup dan Downing, 2017).

\subsection{Status Trofik}

Status trofik di Danau Maninjau yang dihitung berdasarkan parameter TN, TP, klorofil-a dan kecerahan dari tengah danau, PLTA dan KJA dan dapat dilihat pada Tabel 3. 
Tabel 3. Status Trofik Danau Maninjau

\begin{tabular}{ccc}
\hline Parameter & Index & $\begin{array}{c}\text { Status Trofik } \\
\text { Secara Keseluruhan }\end{array}$ \\
\hline TN & 58,44 & \\
TP & 96,86 & 63,39 (Eutrofik) \\
Klorofil-a & 50,19 & \\
Kecerahan & 48,07 & \\
\hline
\end{tabular}

Konsentrasi TN, klorofil-a dan kecerahan di Danau Maninjau tergolong status eutrofik sedangkan konsentrasi TP berbeda dengan kondisi parameter lainnya yaitu hipertrofik. Secara keseluruhan parameter status trofik Danau Maninjau berada pada status eutrofik dengan index 63,39. Eutrofik adalah status trofik danau yang memiliki kandungan unsur hara yang tinggi yang menunjukan adanya peningkatan jumlah fosfor dan nitrogen (Boqiang et al, 2013)

Status trofik Danau Maninjau sangat fluktuatif, pada tahun 2005 sampai 2007 berada pada mesotrofik kemudian meningkat menjadi kondisi eutrofik pada tahun 2008 sampai 2013 sehingga pada tahun 2018 berada pada kondisi hipertrofik (Nomosatryo et al, 2016; Sulastri et al, 2019). Jika dibandingkan dengan status trofik yang diperoleh saat ini maka status trofik Danau Maninjau cenderung menurun akibat dari penurunan jumlah KJA. Klorofil dan kecerahan juga sangat mewakili kondisi trofik danau, klorofil yang tinggi akan berbanding terbalik pada kecerahan danau (El-serehy et al, 2018). KJA merupakan penyebab utama penyumbang nutrien seperti fosfor di Danau Maninjau (Lukman et al, 2015). Status trofik berdasarkan parameter TP jika dibandingkan dengan Peraturan Kementrian Lingkungan Hidup No 28 Tahun 2009 berada pada kondisi hipertrofik. Tingginya kandungan fosfor di Danau Maninjau mengakibatkan penurunan jenis fitoplankton sehingga terjadi blooming Cyanobacteria (Sulastri et al, 2019) Semakin tinggi status trofik danau maka semakin menurun jenis fitoplankton yang ada pada perairan. Kondisi ini dapat terlihat dari tahun 2009 hingga 2018 di Danau Maninjau yang mengalami penurunan fitoplankton berbanding terbalik dengan keadaan status trofiknya (Sulastri et al, 2019).

\subsection{Beban Pencemar Total Nitrogen dan Total Fosfat}

Beban pencemar yang mempengaruhi kualitas air Danau Maninjau berasal dari KJA, pemukiman, pertanian, peternakan dan hotel. KJA merupakan aktivitas terbesar penyumbang TN dan TP yang menyumbangkan beban pencemar hingga $87 \%$ dan 93\% dibandingkan sumber pencemar lainnya. Tabel 4 menunjukan kadar TN pada Ikan Nila dan pakan sebesar $10,52 \mathrm{~kg} /$ tahun dan pakan $25,47 \mathrm{~kg} /$ tahun serta kadar TP sebesar 7,9 kg/tahun dan 14,99 $\mathrm{kg} /$ tahun. Produksi ikan dan pakan di Danau Maninjau pada tahun 2019 sebesar 18.803,36 ton/tahun dan 27.652 ton/tahun yang mengakibatkan beban pencemar TN dan TP masuk ke perairan Danau Maninjau sebesar 777,90 ton/tahun dan 464,37 ton/tahun. Jumlah ini menunjukan beban pencemar TP yang dihasilkan lebih rendah daripada TN akibat dari komposisi pakan. Lukman memperoleh kondisi yang sama dengan beban pencemar berasal dari KJA sebesar $1.701,70$ ton/tahun (TN) dan 269,05 ton/tahun (TP) dengan jumlah KJA 18.630 unit, jumlah ini menunjukan adanya penurunan beban pencemar TN dan TP yang dihasilkan oleh KJA (Lukman et al, 2015).

Table 4. Beban Pencemar Total Nitrogen dan Total Fosfat

\begin{tabular}{lcc}
\hline \multicolumn{1}{c}{ Aktifitas } & $\begin{array}{c}\text { Beban pencemar TN } \\
\text { (ton/tahun) }\end{array}$ & $\begin{array}{c}\text { Beban pencemar TP } \\
\text { (ton/tahun) }\end{array}$ \\
\hline Pemukiman & & 11,01 \\
Menggunakan septik tank & 66,11 & 2.44 \\
Tanpa septik tank & 14,62 & \\
Pertanian & & 25,10 \\
Sawah & 50,20 & 0,281 \\
Peternakan & 1,10 & 2,31 \\
Hotel & 13,90 & 505,68 \\
KJA & 777,90 & 505,68 \\
Total & 923,86 & \\
\hline
\end{tabular}


Kandungan TN dan TP setiap pakan tergantung komposisi merk, semakin tinggi kadar nutrien pada pakan maka kandungan TN dan TP semakin meningkat (Syandri et al, 2018). Hasil survei menunjukan para pemilik KJA menebar pakan dengan tidak memperhatikan dosis setiap pemberian pakan. Kondisi ini akan mengakibatkan pemberian pakan yang tidak efektif dan berakibat terjadinya akumulasi sisa pakan di perairan. Hal ini dapat dilihat bahwa $65 \%$ sumber nitrogen berasal dari pakan ikan (Vanni, 2014; Neto and Ostrensky, 2015). Syandri menguji kadar nitrogen dan fosfor pada 4 jenis ikan dan memperoleh secara berurutan kandungan tertinggi yaitu ikan nila, gurame, mas dan lele. Tingginya kandungan fosfor dan nitrogen pada Ikan Nila dipengaruhi oleh FCR dan kebiasaan makan pada ikan (Syandri et al, 2018). Semakin tinggi FCR maka semakin tinggi pula konsentrasi nutrien yang dihasilkan. FCR yang diperoleh adalah 1.88 sedangkan FCR yang baik untuk budidaya Ikan Nila adalah 1,5. Hal ini menunjukan belum efisiennya pemberian pakan di Danau Maninjau yang masih melebihi batas nilai FCR yang baik untuk budidaya ikan nila. Pemberian pakan yang belum efisien mengakibatkan banyaknya sisa pakan yang tidak dimakan oleh ikan sehingga pakan mengendap di dasar perairan.

Pemukiman memberikan potensi beban pencemar sebesar 80,73 ton/tahun (TN) dan 13,45 ton/tahun (TP). Secara keseluruhan dari total beban pencemar, pemukiman memberikan kontribusi hingga 6,3\% untuk TN dan 2\% untuk TP ke Danau Maninjau. Beban pencemar ini dipengaruhi oleh laju pertumbuhan penduduk hingga $0,74 \%$ setiap tahunnya. Pada tahun 2007 jumlah penduduk di Danau Maninjau berjumlah 30.532 jiwa, angka ini kemudian meningkat setiap tahunnya hingga pada tahun 2019 berjumlah 35.309 jiwa. Machbub memperoleh beban pencemar TP 2,3 ton/tahun dengan jumlah penduduk 30.532 jiwa (Machbub, 2010). Salah satu aktivitas yang menyebabkan tingginya kandungan TP adalah penggunaan detergen yang mampu merangsang pertumbuhan alga dan terjadinya eutrofikasi (Ekere et al, 2015). Hasil penyebaran kuisioner diketahui bahwa 95\% masyarakat sudah menggunakan septik tank dan sisanya belum menggunakan septik tank. Beban pencemar yang dihasilkan menggunakan septik tank dan tanpa septik tank adalah 66,11 ton/tahun dan 14,62 ton/tahun (TN) serta 11,01 ton/tahun dan 2,44 ton/tahun (TP).

Beban pencemar selanjutnya berasal dari pertanian, peternakan dan hotel. Namun, beban pencemar yang dihasilkan masih minim dan tidak terlalu berpengaruh dalam kualitas air di Danau Maninjau jika dibandingkan dengan KJA. Pertanian memberikan kontribusi beban pencemar TN dan TP yaitu 50,20 ton/tahun dan 25,10 ton/tahun. Perbandingan TN dan TP diperoleh hampir 1:2 yang disebabkan oleh kandungan nitrogen pada pupuk lebih tinggi daripada fosfor (Suwarno, 2013). Luas sawah di Danau Maninjau mengalami penurunan akibat ahli fungsi lahan yang menjadikan lahan sawah menjadi tempat budidaya Ikan Nila. Data Badan Pusat Statistika (BPS) Kecamatan Tanjung Raya dalam angka, luas sawah pada tahun 2015 yaitu 2.512 Ha kemudian menurun hingga 2.510 Ha. Kondisi ini mengakibatkan beban pencemar yang dihasilkan dari aktivitas pertanian mengalami penurunan.

Data BPS Kecamatan Tanjung Raya dalam angka, jenis hewan ternak yang dipelihara masyarakat Danau Maninjau adalah sapi (1.334 ekor), kerbau (333 ekor), kambing (529 ekor), ayam (12.246 ekor) dan itik (1.179 ekor). Total beban pencemar TN dan TP yang dihasilkan adalah 1,10 ton/tahun (TN) dan 0.28 (ton/tahun). Masyarakat Danau Maninjau menggunakan rumput sebagai makanan utama dalam ternak kerbau, sapi dan kambing. Untuk ayam dan itik para petani memberikan dedak dan jagung giling sebagai sumber makanan. Jumlah hewan ternak seperti kerbau, kambing dan ayam mengalami penurunan setiap tahunnya. Jumlah pengunjung hotel di Danau Maninjau pada tahun 2015 adalah 7.056 jiwa, jumlah ini diperikirakan menurun setiap tahunnya akibat dari kualitas air yang menurun.

Hasil beban pencemar menunjukan penyumbang TN dan TP terbesar berasal dari KJA yaitu 84,20 \% dan $91,83 \%$. Aktivitas selanjutnya yang memberikan kontribusi terbesar untuk TN adalah pemukiman sedangkan untuk TP adalah pertanian. Peternakan dan hotel memberikan kontribusi yang minim ke Danau Maninjau akibat dari penurunan aktivitas hotel dan jumlah ternak. Secara keseluruhan beban pencemar TN dan TP yang ada di Danau Maninjau dipengaruhi oleh aktivitas KJA.

\subsection{Daya Tampung Total Nitrogen dan Total Fosfat}

Dari perhitungan menggunakan persamaan 4 diperoleh daya tampung TN untuk kondisi mesotrofik $2.357,82$ ton/tahun sedangkan TP untuk mesotrofik dan oligotrofik adalah 188,62 ton/tahun dan 62,87 ton/tahun (Tabel 5.) Kondisi ini menunjukan bahwa beban pencemar yang dihasilkan oleh TN masih belum melebihi daya tampung mesotrofik sedangkan beban pencemar TP telah melebihi daya tampung mesotrofik maupun oligotrofik. Beban pencemar TN yang masuk ke Danau Maninjau masih 50\% dari jumlah daya tampungnya berbeda dengan beban pencemar TP yang dihasilkan jauh melebihi daya tampung dengan perbandingan 3,5:1. Umumnya beban pencemar yang memberikan kontribusi besar ke Danau Maninjau berasal dari KJA baik untuk TN maupun TP. Daya tampung TN yang belum melebihi beban pencemar dikarenakan kadar TN yang diperbolehkan cukup tinggi yaitu $750 \mathrm{mg} / \mathrm{m}^{3}$. Nilai ini sangat berbeda jauh dengan batas maksimum kadar TP untuk mesotrofik dan oligotrofik yaitu $30 \mathrm{mg} / \mathrm{m}^{3}$ dan $10 \mathrm{mg} / \mathrm{m}^{3}$. Untuk mencapai kondisi mesotrofik dan oligotrofik maka perlu pengurangan beban pencemar TP hingga 71,34\% dan $90,44 \%$. 
Tabel 5. Daya Tampung Total Nitrogen dan Total Fosfat

\begin{tabular}{|c|c|c|c|c|c|}
\hline \multirow[t]{2}{*}{ Parameter } & \multirow{2}{*}{$\begin{array}{c}\text { TN } \\
\text { Mesotrofik } \\
\text { (ton/tahun) }\end{array}$} & \multirow{2}{*}{$\begin{array}{c}\text { Total Beban } \\
\text { Pencemar TN } \\
\text { (ton/tahun) }\end{array}$} & \multicolumn{2}{|c|}{ TP } & \multirow{2}{*}{$\begin{array}{c}\text { Total Beban } \\
\text { Pencemar TP } \\
\text { (ton/tahun) }\end{array}$} \\
\hline & & & $\begin{array}{c}\text { Mesotrofik } \\
\text { (ton/tahun) }\end{array}$ & $\begin{array}{c}\text { Oligotrofik } \\
\text { (ton/tahun) }\end{array}$ & \\
\hline
\end{tabular}

Pengurangan beban pencemar TP dilihat dari sumber terbesar yaitu KJA sehingga perlu dilakukan pembatasan jumlah KJA. Jumlah pengurangan TP untuk kondisi mesotrofik pada penelitian ini menurun jika dibandingkan dengan penelitian sebelumnya yaitu 74\% (Machbub, 2010) yang menghasilkan beban pencemar 859.18 ton/tahun. Kondisi ini terjadi karena perubahan kedalaman rata-rata Danau Maninjau.

Perhitungan daya tampung dipengaruhi oleh kedalaman rata-rata danau, luas danau dan laju penggantian air. Kedalaman rata-rata Danau Maninjau mengalami penurunan berdasarkan data Dinas Pekerjaan Umum Kabupaten Agam. Pada tahun 2005, kedalaman rata-rata yaitu $105 \mathrm{~m}$ dan pada tahun 2019 menjadi 104,84 m. Namun, Danau Maninjau masih dalam kategori perairan yang dalam. Daya tampung TP di Danau Kariba cukup rendah dibandingkan Danau Maninjau karena perbedaan kedalaman hingga 72,14\% (Mhlanga et al, 2013). Luas area danau juga salah satu faktor penentu daya tampung, Danau Maninjau memiliki luas 9.763.000 $\mathrm{m}^{2}$ sedangangkan Granu Jati hanya memiliki luas 1.734.223.07 $\mathrm{m}^{2}$ (Mahmudi et al, 2019). Perbedaan luas hampir 80\% membuat daya tampung Granu Jati lebih rendah jika dibandingkan Danau Maninjau. Kondisi ini menunjukan bahwa luas danau memiliki pengaruh terhadap daya tampung.

\section{Kesimpulan}

Konsentrasi TN yang diperoleh dari semua lokasi pengamatan berada pada status oligotrofik hingga eutrofik, TP berada pada kondisi mesotrofik-eutrofik sedangkan klorofil secara merata berada pada kondisi eutrofik. Secara keseluruhan status trofik Danau Maninjau berada pada kondisi eutrofik, cenderung telah mengalami penurunan dari kondisi hipertrofik sebelumnya akibat dari penurunan KJA. Konsentrasi TN dan TP memiliki hubungan yang kuat terhadap klorofil-a. Rasio TN:TP<10 mengindikasikan TN sebagai pembatas kesuburan yang menunjukan konsentrasi nitrogen sangat dominan pada perairan.

Beban pencemar terbesar berasal dari KJA dengan 12312 unit yang menyumbangkan $91.07 \%$ TN dan 93 \% TP ke Danau Maninjau. Kondisi ini cenderung menurun jika dibandingkan dengan jumlah KJA pada tahun sebelumnya yaitu 15.310 unit dengan mereduksi $19.58 \%$ beban pencemar. Daya tampung TN untuk kondisi mesotrofik masih jauh dari beban pencemar yang dihasilkan yakni 50\% dari total beban pencemar. Kondisi yang berbeda ditunjukan oleh beban pencemar TP yang sudah melebihi daya tampungnya baik untuk kondisi mesotrofik ataupun oligotrofik. Perlu adanya penurunan TP hingga $71.34 \%$ dan $90.44 \%$ untuk kondisi mesotrofik dan oligotrofik. Dari perhitungan beban pencemar dan daya tampung TP menunjukan KJA sebagai aktivitas utama yang memberikan kontribusi terbesar sedangkan aktivitas lainnya hanya menyumbangkan 7\%. Oleh karena itu perlu adanya kajian lebih lanjut dalam pembatasan TP akibat dari KJA seperti pengurangan jumlah KJA yang akan berdampak terhadap penurunan penggunaaan pakan dan produksi ikan.

\section{DAFTAR PUSTAKA}

Beveridge, B. (2004). Cage Aquaculture.

Boqiang, Q. I. N., Guang, G. A. O., Guangwei, Z. H. U., Yunlin, Z., Yuzhi, S., Xiangming, T., ... Jianming, D. (2013). Lake eutrophication and its ecosystem response, 58(9), 961-970. https://doi.org/10.1007/s11434-0125560-x

Carlson, R. E. (1977). A trophic state index for lakes 1, 22(March).

Chirico, N., Ant, D. C., Pozzoli, L., Marinov, D., Malag, A., Sanseverino, I., ... Lettieri, T. (2020). Cyanobacterial Blooms in Lake Varese : Analysis and Characterization over Ten Years of Observations.

Ekere, N. R., Ihedioha, J. N., \& Bright, A. A. (2015). Assessment of the Levels of Phosphates in detergents samples synthesis of potash alum from waste aluminum foil and aluminum scrap. Int. J. Chem. Sci, (September), 11451152.

El-serehy, H. A., Abdallah, H. S., Al-misned, F. A., Al-farraj, S. A., \& Al-rasheid, K. A. (2018). Saudi Journal of Biological Sciences Assessing water quality and classifying trophic status for scientifically based managing the water resources of the Lake Timsah, the lake with salinity stratification along the Suez Canal. Saudi Journal of Biological Sciences, 25(7), 1247-1256. https://doi.org/10.1016/j.sjbs.2018.05.022

Filstrup, C. T., Downing, J. A., \& Downing, J. A. (2017). Relationship of chlorophyll to phosphorus and nitrogen in nutrient-rich lakes Relationship of chlorophyll to phosphorus and nitrogen in nutrientrich lakes. Inland Waters, 7(4), 385-400. https://doi.org/10.1080/20442041.2017.1375176

Gunes, K. (2008). Point and nonpoint sources of nutrients to lakes - ecotechnological measures and mitigation methodologies - case study, 4, 116-126. https://doi.org/10.1016/j.ecoleng.2008.07.004

Imar, F. A. D., Utri, M. A. P., Idyastuti, E. N. W., \& Hristiani, C. 
(2008). Hubungan perbandingan total nitrogen dan total fosfor dengan kelimpahan chrysophyta di perairan, (1955).

Lukman, Setyobudiandi, I., Muchsin, I., \& Hariyadi, S. (2015). Impact of Cage Aquaculture on Water Quality Condition in Lake Maninjau, West Sumatera Indonesia, 4531, 120-137.

Lv, J., Wu, H., \& Chen, M. (2011). Limnologica Effects of nitrogen and phosphorus on phytoplankton composition and biomass in 15 subtropical , urban shallow lakes in Wuhan, China. Limno Logica, 41(1), 48-56. https://doi.org/10.1016/j.limno.2010.03.003

Machbub, B. (2010). Model perhitungan daya tampung beban pencemaran air, 129-144.

Mahmudi, M., Lusiana, E. D., Arsad, S., Buwono, N. R., Darmawan, A., Nisya, T. W., \& Gurinda, G. A. (2019). A study on phosphorus-based carrying capacity and trophic status index of floating net cages area in Ranu Grati , Indonesia, 12(5), 1902-1908.

Mazón, M. J., Piedecausa, M. A., Hernández, M. D., \& García, B. G. (2007). Evaluation of environmental nitrogen and phosphorus contributions as a result of intensive ongrowing of common octopus (Octopus vulgaris ), 266, 226-235. https://doi.org/10.1016/j.aquaculture.2007.01.001

Mhlanga, L., Mhlanga, W., \& Mwera, P. (2013). The application of a phosphorus mass balance model for estimating the carrying capacity of Lake Kariba, 316-319. https://doi.org/10.3906/vet-1110-37

Morris, J., \& Oceanic, N. (2015). Marine Cage Culture \& The Environment, https://doi.org/10.13140/RG.2.1.2382.9841

Neto, R. M., \& Ostrensky, A. (2015). Nutrient load estimation in the waste of Nile tilapia Oreochromis niloticus ( L .) reared in cages in tropical climate conditions, 13091322. https://doi.org/10.1111/are.12280

Nguyen, D., \& Hong, T. (2014). Cobia cage culture distribution mapping and carrying capacity assessment in Phu Quoc , Kien Giang province, (January 2013).

Nomosatryo, C. H. and S. (2016). Changes in water quality and trophic status associated with cage aquaculture in Lake Maninjau , Indonesia. IOP Earth and Environmental Science. https://doi.org/10.1088/1755-

\section{$1315 / 31 / 1 / 012027$}

Oakley, J. (2014). Modeling the Aquaculture Carrying Capacity Of Lake Toba , North Sumatra , Indonesia By, 1-35.

Peraturan Daerah Kabupaten Agam. Pengelolaan kelestarian kawasan danau maninjau (2014).

Pick, F. R., Fastner, J., Rohrlack, T., Dolman, A. M., \& Ru, J. (2012). Cyanobacteria and Cyanotoxins : The Influence of Nitrogen versus Phosphorus, 7(6) https://doi.org/10.1371/journal.pone.0038757

Quinatto, J., Liz, N., Zambelli, D. N., Souza, D. H., Cardoso, J. T., \& Skoronski, E. (2018). Using the pollutant load concept to assess water quality in an urban river : the case of Carahá River ( Lages , Brazil ) Avaliação da qualidade da água de um rio urbano utilizando o conceito de carga de poluentes : o caso do Rio Carahá ( Lages , Brazil ). https://doi.org/10.4136/1980-993X

Rathore, S. S., Chandravanshi, P., Chandravanshi, A., \& Jaiswal, K. (2016). Eutrophication: Impacts of Excess Nutrient Inputs on Aquatic Ecosystem, 9(10), 89-96. https://doi.org/10.9790/2380-0910018996

Sulastri, Cynthia Henny, S. N. (2019). Keanekaragaman fitoplankton dan status trofik Perairan Danau Maninjau di Sumatera Barat, Indonesia Phytoplankton diversity and trophic status of Lake Maninjau, West Sumatra, Indonesia, 5(Chalar 2009), 242-250. https://doi.org/10.13057/psnmbi/m050217

Suwarno, D. (2013). Potensi dan masalah sampah di jawa tengah ( studi kasus pengadaan pupuk organik yang, $1-9$.

Syandri, H., \& Mardiah, A. (2018). Nitrogen and Phosphorus Waste Production from Different Fish Species Cultured at Floating Net Cages in Lake Maninjau, Indonesia. Asian Journal of Scientific Research, 2, 287-294. https://doi.org/10.3923/ajsr.2018.287.294

Vanni, M. J. (2014). In f reshwater e cosystems, (November 2002). https://doi.org/10.1146/annurev.ecolsys.33.010802. 150519

Vinnerås, B. (2001). Faecal separation and urine diversion for nutrient management of household biodegradable waste and wastewater. 